\title{
Fordító- és tolmácshallgatók gyakornoki tapasztalatai: elvárások és gyakorlatok 2. rész:
}

\section{Szinkrontolmácsolás a szükséges képzés nélkül ${ }^{1}$}

\author{
Seresi Márta \\ E-mail:seresi.marta@btk.elte.hu
}

\begin{abstract}
Kivonat: Az ELTE Fordító- és Tolmácsképző Tanszékének mesterszakos fordító- és tolmácshallgatói az első tanév után szakmai gyakorlaton vesznek részt. A gyakorlatok során előfordul, hogy a megbízók olyan feladatok elvégzésére kérik a hallgatókat, amelyekre a képzés nem készítette fel őket. Kérdőíves kutatásban vizsgáltam meg, milyen gyakran kérik a hallgatókat arra, hogy a $\mathrm{C}$ nyelvük irányába dolgozzanak vagy szinkrontolmácsoljanak. A válaszokból kiderült, hogy az ilyen kérések nagyon gyakoriak. A hallgatók az esetek túlnyomó többségében elvállalják a feladatot, és elégedettek is a teljesítményükkel, amiben nagy szerepet játszanak a kapott visszajelzések. Kutatásom eredményeit két írásban ismertetem: ebben a cikkben a szinkrontolmácsolással kapcsolatos tapasztalatokat foglalom össze.

Kulcsszavak: fordító- és tolmácsképzés, mesterképzés, szakmai gyakorlat, szakmai standardok, szinkrontolmácsolás, felkészülés, visszajelzés
\end{abstract}

\section{Bevezetés}

Ez a cikk az Iránytü az egyetemi tolmácsképzéshez címü kötetben megjelent írásom (Seresi 2020) folytatása. Az első cikkben részletesen ismertettem a kutatásom hátterét, de az alábbiakban is összefoglalom mindazt, ami az érthetőséghez szükséges. A kutatás megtervezéséről, illetve az itt nem ismertetett eredményeiről az első írásomból lehet részletesebben tájékozódni.

A kutatásomhoz az ELTE Fordító- és Tolmácsképző Tanszékén tanuló hallgatók szakmai beszámolói adták az inspirációt. A szakfordító- és tolmács mesterszakos hallgatóknak ugyanis a képzés részeként legalább 60 munkaórás szakmai gyakorlatot kell teljesíteniük. Erre a kétéves mesterképzés első tanéve

1 Ez a cikk az Iránytü az egyetemi tolmácsképzéshez című kötetben megjelenő cikk (Seresi 2020) második része. Az első részben azt vizsgáltam meg, milyen gyakran kérték a gyakorlaton részt vevő hallgatókat arra, hogy a $\mathrm{C}$ nyelvükre tolmácsoljanak vagy fordítsanak.

Hivatkozás: Seresi M. 2019. Fordító- és tolmácshallgatók gyakornoki tapasztalatai: elvárások és gyakorlatok. 2. rész: Szinkrontolmácsolás a szükséges képzés nélkül. Forditástudomány 21. évf. 2. szám 63-79. DOI: https://doi.org/10.35924/fordtud.21.2.5 
után kerül sor. Az első évben a hallgatók fordítást és tolmácsolást is tanulnak, ám a második tanévben már specializálódnak vagy az egyik, vagy a másik tevékenységre. A hallgatók jellemzően fordítóirodákhoz, állami intézményekhez vagy nonprofit szervezetekhez mennek gyakorlatra, majd márciusban Power Point bemutató keretében számolnak be az ott szerzett tapasztalataikról. Ez a beszámoló segítséget jelent az elsőéves hallgatóknak a gyakorlati hely kiválasztásában, és nagyon sokszor érdekes vitát is inspirál a munkakörülményekről, valamint a szakmai standardokról.

A 2018-2019-es tanév szakmai gyakorlati beszámolóit hallgatva az a szubjektív érzésem támadt, hogy a hallgatókat viszonylag gyakran kérik a gyakorlatukon olyan feladatok végrehajtására, amelyekre a mesterképzés során nem volt alkalmuk felkészülni. Ennek vagy az az oka, hogy az adott tevékenység eleve nem része a mesterképzésnek (például a szinkrontolmácsolás), vagy az, hogy nem is bátorítjuk a hallgatókat az adott tevékenység (például az A nyelvről C nyelvre történő tolmácsolás vagy fordítás) kipróbálására. Mivel kíváncsi voltam, hogy mennyire megalapozott ez a benyomásom, illetve, hogy ezek a feladatok milyen hatással vannak a hallgatóinkra, úgy döntöttem, hogy kérdöívben kérdezem meg a hallgatókat mindezekről.

$\mathrm{Az}$ alábbiakban röviden ismertetem a szinkrontolmácsolás elkezdésével, illetve a pedagógiai folyamatba való bevezetésével kapcsolatos szakirodalmat, majd rátérek a kutatásomra. Röviden bemutatom a használt kérdőívet, majd ismertetem a hallgatók válaszait. Végül megpróbálok tanulságokat levonni és tendenciákat azonosítani, és kijelölöm a további kutatás lehetséges irányait is.

\section{Irodalmi áttekintés}

A fordító- és tolmácsképzés hagyományai a huszadik század közepe táján alakultak ki, és ezt követően szilárdultak meg (G. Láng 2002, Seresi 2019). Mivel ebben az időben a képzés a nemzetközi intézményekben és magas presztízsű rendezvényeken végzett konferenciatolmácsolásra koncentrált, a képző intézmények tananyagában a nagyszakaszos konszekutív tolmácsolás, valamint a szinkrontolmácsolás szerepelt. Az alábbiakban röviden definiálom ezt a két tolmácsolástípust, majd áttekintem, hogy a szakirodalom mit ír a szinkrontolmácsolás elsajátításáról és a gyakorlásának feltételeiről.

\subsection{Definíciók}

Konszekutív tolmácsolás esetén a tolmács hosszabb beszédszakaszokat tolmácsol, közvetlenül azok elhangzása után. Ehhez szükség van szisztematikus jegyzeteléstechnika használatára is. A szakaszok hossza változó, néhány mondattól 10 percig is terjedhet, de jellemzően 5 perc körüli (G. Láng 2002, Horváth 2012). Régebben előfordult, hogy akár 15-20 perces szakaszokat is kellett tolmácsolni, ami látványos szereplési lehetőséget jelentett a tolmácsoknak. Ma már a közönség és az előadók is jobban szeretik a rövidebb, dinamikusabb szakaszokat (Kalina 2002). A konszekutív tolmácsolás előnye, hogy a tolmács már azelőtt átfogó képet 
kaphat az előadó gondolatmenetéről, hogy ő maga megkapná a szót; hosszabb szakaszok esetén pedig megszakítások sem törik meg a logikai összefüggéseket.

Szinkrontolmácsolás során a tolmács fülhallgatón keresztül hallgatja a beszélőt, és ő maga is mikrofonba beszél. Így képes folyamatosan, néhány másodperces lemaradással tolmácsolni az elhangzottakat. A közönség szintén fülhallgatón keresztül hallgatja a tolmácsot. Ehhez szükség van egy megfelelően felszerelt és hangszigetelt tolmácskabinra is. Szinkrontolmácsolás esetén a kabinban 2 tolmács foglal helyet, és az eredeti szöveg nehézségétől függően 20-30 percenként váltják egymást. A szinkrontolmácsolás előnye, hogy gyakorlatilag nem jár időveszteséggel, mivel valós idejü.

\subsection{A szinkrontolmácsolás elsajátítása}

A szinkrontolmácsolás a huszadik század elején jelent meg, és a nürnbergi perekkel lett általánosan elfogadott. Nincs még száz éve, hogy szinkrontolmácsolásról beszélhetünk, és épp elég jól dokumentált ennek a tolmácsolási módnak a története ahhoz, hogy tudjuk: kezdetben nem léteztek, hiszen nem is létezhettek képzett szinkrontolmácsok. A nürnbergi perekhez például az akkoriban a piacon ismert konszekutív tolmácsok, valamint a többnyelvü laikusok közül válogattak tolmácsokat. A nyugati országokban azonban hamarosan megjelentek a szinkrontolmácsoláshoz kapcsolódó képzések, és az vált elfogadottá, hogy a tolmácsok csak ilyen irányú képzés után üljenek be a tolmácskabinokba (Szabari 2002).

Magyarországon csak a hetvenes évek végén jelent meg a tolmácsképzés, így a szinkrontolmácsolást meghatározó „nagy öregek” generációja formális képzés nélkül, a munka végzése közben tanulta ki a szakmát. Ráadásul ebben az időszakban viszonylag kevesen beszéltek a keleti blokkban idegen nyelveket. Így, amikor tolmácsra volt szükség, nem volt túl sok választási lehetőség: ha valaki magas szintủ nyelvtudással rendelkezett, betölthette akár a szinkrontolmács feladatait is. Ennek az időszaknak köszönhető, hogy a szinkrontolmácsolással kapcsolatban kialakult egyfajta misztikus elképzelés, amely szerint ez afféle megfoghatatlan, szinte mágikus készség, amely képzéssel nem elsajátítható. Egy 1999-es felmérés szerint az ország „vezető tolmácsainak” $70 \%$-a még ekkor is mindenféle képzettség nélkül gyakorolta a szakmát (Szabari 2002).

\subsubsection{A szinkrontolmács-képzés alapelvei, elsajátítandó készségek}

Tagadhatatlan, hogy a tolmácsolás és a szinkrontolmácsolás elsajátítható a gyakorlatban is. A tolmácsképzés azonban abból az elképzelésből indul ki, hogy formalizált, szervezett keretek között, az elődök tapasztalatainak tananyaggá sürítésével ez a tanulási folyamat felgyorsítható, és hatékonyabbá, eredményesebbé tehető (Klaudy 1999, AIIC 2001, Seresi 2016, Seresi 2019). Ennek megfelelően már a huszadik század derekán megjelentek többé-kevésbé rendszerezett írások a konferenciatolmácsolás oktatásának kérdéseiről. Ilyen volt például Herbert könyve is (1952), aki úgy vélte, a szinkrontolmácsokat konszekutív tolmácsokból kell képezni. 
A konferenciatolmács-képzés egyik legrendszerezettebb és leginkább meghatározó módszertanát az interpretatív modell alapján dolgozta ki Seleskovitch és Lederer (2002). A modell szerint a legfontosabb készség, amelyet a leendő tolmácsnak el kell sajátítania, az üzenet elemzése: képesnek kell lennie a forrásnyelvi formától elszakadni, és a megértett, elemzett gondolatot a célnyelvre jellemző struktúrákkal visszaadni. Ez kezdetben még akkor is nehéz lehet, ha a beszédpercepció (hallgatás) és a beszédprodukció (tolmácsolás) időben elkülönül, egymást követi. Ezért a tolmácsképzés először rövid „gist recall” gyakorlatokkal kezdődik, amely során legfeljebb 2-3 perces beszédeket kell a logikai összefüggésekre koncentrálva a célnyelven visszaadni. A beszéd hosszának és összetettségének növelésével, illetve a jegyzeteléstechnika bevezetésével érkezik el a képzés a tulajdonképpeni konszekutív tolmácsoláshoz (G. Láng 2002, Seleskovitch és Lederer 2002).

A párizsi iskola egészen odáig megy, hogy a szinkrontolmácsolást csak akkor szabad bevezetni, amikor a konszekutív tolmácsolásban már megbízhatóan megszilárdultak a szükséges mechanizmusok. Ha ezzel kapcsolatban az oktatónak kételyei vannak, Seleskovitch és Lederer azt javasolják, vizsgán mérje fel a hallgatók készségeit. Szerintük ugyanis csak akkor lehet a szinkrontolmácsolást elsajátítani, ha a konszekutív tolmácsolás már kiválóan megy. Ha nem így van, a beszédpercepció és a beszédprodukció egyidejűsége miatt a hallgató nem lesz képes elkerülni a nyelvi interferenciát, és nem biztos, hogy elemző tolmácsolást fog végezni: nagy lesz a kísértés, hogy ehelyett egyszerúen a szó szerinti megfelelők papagájszerú elsorolásával, transzkódolással oldja meg a feladatot (Seleskovitch és Lederer 2002).

Herbert és Seleskovitch nyomdokaiba lépve a legtöbb tolmácsképzéssel foglalkozó írás magától értetődőnek tekinti, hogy konszekutív tolmácsokból képezünk szinkrontolmácsokat. A képzés során a konszekutív módban kialakított készségeket kell átvinni a szimultán módba, bár ezek átvihetőségét tudományosan nem tesztelték vagy bizonyították eddig. Ezért vannak olyan szerzők is, például Setton és Dawrant (2016), akik nem ragaszkodnak hozzá dogmaszerüen, hogy a szinkrontolmácsolás bevezetése elött a hallgatók mindenképpen mélyedjenek el a konszekutív tolmácsolásban is. Ők úgy vélik, hogy ha rögtön a képzés elején elkezdődik a szinkrontolmácsolás oktatása, több idő jut ennek a nehéz, de nagyon is piacképes tevékenységnek az elsajátítására. De még ők is hangsúlyozzák, mennyire fontos, hogy a szinkrontolmácsolást előkészítő gyakorlatok vezessék be, és hogy kezdetben a gyakorlás oktatói felügyelet és visszajelzés mellett történjen. Ha ugyanis a kezdő tolmácshallgatók oktatói felügyelet nélkül próbálják ki magukat szinkronhelyzetben, a megerőltető feladat hatására még azelőtt hibás mechanizmusokat alakíthatnak ki és szokhatnak meg, hogy a képzésük egyáltalán elkezdődött volna (Setton és Dawrant 2016).

A szinkrontolmácsolás bevezető szakaszának legfontosabb célkitűzése, hogy a hallgatók a megfelelő szintre fejlesszék a figyelemmegosztásukat. Emellett ebben a szakaszban stratégiákat kell kialakítaniuk annak ellensúlyozására is, hogy a konszekutív tolmácsolással ellentétben szinkronban a tolmácsnak azelőtt kell elkezdenie beszélni, hogy kiderülne számára, milyen irányba tart a felszólaló gondolatmenete (Jones 1998, Seleskovitch és Lederer 2002). A képzés to- 
vábbi előnye, hogy felkészíti a hallgatókat a szinkrontolmácsoláskor tapasztalható igen nagymértékủ stressz kezelésére (Zeier 1997).

\subsubsection{A szinkrontolmácsoláshoz szükséges feltételek tudatositása}

A képzés másik fontos feladata, hogy tudatosítsa a hallgatókban, milyen a professzionális viselkedésmód (Setton és Dawrant 2016), illetve milyen munkakörülmények között lehet megfelelő szinkronteljesítményt nyújtani (Seresi 2019). Ahhoz, hogy a tolmácsok a szükséges körülmények biztosítását kérhessék a megbízóktól, tisztában kell lenniük vele, hogy ezekre szükségük van, és esetenként képesnek kell lenniük megindokolni, miért. Ilyen szükséges feltétel például a hangszigetelt, a teremre jó rálátást biztosító tolmácskabin, a megfelelő fülhallgató, az egyénileg állítható tolmácspanel, vagy a teremben jól elhelyezett (és be is kapcsolt) mikrofon.

Ugyanilyen fontos feltétel még, hogy a tolmácsoknak legyen kabintársuk, akivel húsz-harminc percenként válthatják egymást, hiszen harminc perc után mérhetően nő a félrefordítások száma a tolmácsok teljesítményében (Moser-Mercer et al 1998). A kabintárs segíthet a számok és nevek lejegyzetelésében (Chmiel 2008), illetve az esetleges dokumentumok tolmácsolás közbeni nyomon követésében (Rohonyi 2018), vagy bármilyen más felmerülő nehézség megoldásában. Ezt a fajta együttmüködést azonban be kell gyakorolni, ahogy azt is el kell sajátítani, milyen viselkedés támogató, és milyen viselkedés zavaró a kabinban (Gile 1995, Chmiel 2008). A kabinba felkészületlenül érkező tolmácsok azonban sokszor még a tolmácspult használatával sincsenek tisztában.

\subsubsection{Az oklevél kibocsátása}

A képesítő okleveleket kibocsátó tolmácsképző intézmények nem csak a szaktudást adják tovább a hallgatóiknak, hanem "gatekeeper” funkciót is betöltenek, amivel elsősorban az ügyfelek érdekeit és a szakma jó hírnevét kívánják megvédeni. Természetesen vitatható, hogy mennyire jelent garanciát a képző intézmények által kiadott diploma arra, hogy a birtokosa valóban meg fogja állni a helyét a piacon, de az bizonyos, hogy valamilyen szürésre, a piachoz való hozzáférés valamilyen jellegű ellenőrzésére szükség van. Ezt a korlátozást a legtöbb szakmában (jogász, orvos) vita nélkül elfogadják, azonban a nyelvi közvetítői szakmában még nyugaton sem tartja mindenki indokoltnak.

Ugyanakkor ne felejtsük el, hogy a tolmács felelőssége tevékenységének azonnaliságából adódóan igen nagy: az egyszer kimondott szót már nem lehet átszerkeszteni, lektorálni vagy más módon korrigálni. A piacra kilépő tolmács ennek megfelelő szakmai felkészültséggel kell, hogy rendelkezzen (Setton és Dawrant 2016).

\subsection{A hallgatók szintje a szakmai gyakorlat teljesítésekor}

A szakmai gyakorlaton részt vevő hallgatók egy tanéven keresztül tanulták a konszekutív tolmácsolást. Az első év végén jellemzően még nincsenek azon 
a szinten, amit a záróvizsgán elvárunk tőlük. Ilyen értelemben nem teljesítik tehát a párizsi iskola által támasztott feltételt, amely szerint magabiztos konszekutív készségek birtokában kellene csak szinkrontolmácsolással próbálkozniuk.

Ugyanakkor a fentiekben láttuk, hogy a szinkrontolmácsolás történetében nem egyedülálló, hogy valaki szakirányú végzettség nélkül próbálkozzon szinkrontolmácsolással. A hallgatók a mögöttük álló egy év alatt megismerkedtek a tolmácsolás alapelveivel: tudják, mire kell törekedniük, és valószínüleg egy laikusnál sokkal tudatosabban monitorozzák is a teljesítményüket. Ezenkívül a megbízóik is tisztában voltak vele, hogy nem „kész”, képzett tolmácsokkal van dolguk, hanem szakmai gyakorlatukat töltő hallgatókkal.

\section{A kutatás ismertetése}

A 2018-2019-es szakmai gyakorlati beszámolók meghallgatásakor három nagyon egyszerü kérdés merült fel bennem: Milyen gyakran kérik a hallgatókat a jelenlegi szakmai standardokkal szembemenő gyakorlatra? Mennyire tudnak megbirkózni az ilyen feladatokkal? Milyen hatással vannak rájuk az ilyen feladatok?

\subsection{A kérdőív összeállítása}

Mivel nem volt sok kérdésem és a kutatásomat gyors pillanatfelvételnek szántam, úgy döntöttem, hogy a kérdőívet a lehető legegyszerübben állítom össze, a lehető legkevesebb kérdéssel. Ebből következően azonban nem kérdeztem rá bizonyos tényezőkre, amelyek az eredmények összesítésekor mégis relevánsnak tüntek. Ezekre a tényezőkre az elemzés során részletesen ki fogok térni.

$\mathrm{Az}$ érintett tanévben összesen 59 hallgató számolt be a szakmai gyakorlatáról: 20 tolmácsszakos és 39 fordító szakos. A hallgatók azonban nem csak a specializációjuk mentén vannak csoportokba osztva, hanem B nyelvük szerint is, amely ebben az évben lehetett angol, német, francia vagy kínai. A tanszéken tanító kollégák segítségével papíralapú kérdőíveket juttattam el az összes nyelvi csoporthoz, és ezekből 48-at kitöltve vissza is kaptam.

Mivel egy hallgató több gyakorlati helyen is járhatott, és egy gyakorlati hely több hallgatót is fogadhatott, úgy döntöttem, hogy az eredmények elemzésekor alapegységként az „egy hallgató egy gyakorlati helyét” fogom használni. Tehát, ha egy hallgató három gyakorlati helyen is volt, az három egységnek fog számítani, míg ha két hallgató volt azonos gyakorlati helyen egyszerre vagy egymás után, az is két egységnek számít majd. A hallgatók és a gyakorlati helyek névtelenségének megőrzése mellett ez tünt az egyetlen átlátható megoldásnak - a névtelenséghez pedig a vizsgált gyakorlatok vitathatósága miatt is ragaszkodtam. 


\subsection{A kérdőív kiosztása, első adatok}

Az elkészült kérdőívet 2019. március 13-án pilot formában két volt MA hallgatónkkal töltettem ki. Ekkor nem ütközött ki a kérdőívben semmilyen hiba, így az elkövetkező két hétben megkértem a kollégáimat, hogy osszák ki a véglegesített kérdőívet a nyelvi csoportjaikban. Összesen 48 kérdőívet kaptam vissza.

A kérdőívekben nem kérdeztem rá, hogy a kitöltő fordító vagy tolmácsszakos volt-e, mivel a gyakorlatokon gyakran mindkét szerepet be kell tölteniük, illetve a tolmácsszakosoknak nem mindig sikerül tolmácsolási gyakorlatot találni. Így csak a hallgatói létszám alapján sejthető, hogy a kitöltők között megközelítőleg kétszer annyi fordító szakos lehetett, mint tolmács.

Arra sem kérdeztem rá, hogy mi volt a kitöltő nyelvkombinációja. Ugyanakkor a kérdőívek áttekintésekor feltünt, hogy az angol C-vel rendelkező hallgatókat gyakrabban kérték, hogy $\mathrm{C}$ nyelvükre dolgozzanak. Ezt annak köszönhetően tudtam megállapítani, hogy a kitöltött kérdőíveket a B nyelvek szerint szétválogatva kaptam meg segítőkész kollégáimtól. Fontos tudni, hogy minden mesterszakos hallgatónknak szerepel az angol nyelv a nyelvkombinációjában, tehát ha nem ez a $\mathrm{B}$ nyelvük, akkor minden esetben angol $\mathrm{C}-\mathrm{vel}$ vesznek részt a képzésben. Ezért tudtam angol C-s és nem angol C-s hallgatókra szétbontani a mintát annak ellenére, hogy a $\mathrm{C}$ nyelvre a kérdőívben nem kérdeztem rá.

Összesen 17 olyan hallgatótól kaptam vissza kérdőívet, akitől egyetlen gyakorlati helyén se kérték se azt, hogy a $\mathrm{C}$ nyelvére dolgozzon, se azt, hogy szinkrontolmácsoljon. Ez azt jelenti, hogy a hallgatóink 2/3-ával előfordult, hogy olyat kértek tőlük, amihez nem volt meg a szakmai felkészültségük. A továbbiakban ugyanakkor már nem az egyes hallgatókra lebontva fogom az eredményeket elemezni, hanem a korábban definiált alapegység szerint ( 1 hallgató 1 gyakorlati helye).

Mielőtt rátérnék az eredmények részletes ismertetésére, ki szeretnék térni a koherencia hibákra is. Előfordult például, hogy a válaszadó azt írta, hogy egyetlen gyakorlati helyen volt, de három helyen is kérték szinkrontolmácsolásra - amivel kapcsolatban semmilyen további kérdésre sem válaszolt. Az ilyen esetekben azt a választ valószínúsítettem, amire az adatok többsége utalt a fenti példában az első kérdésre adott válasz és az utolsó kérdések átugrása azt tette valószínủvé, hogy valójában egyetlen helyen sem kérték szinkrontolmácsolásra, csak rossz négyzetbe húzta az x-et. Hasonlóan utólag korrigáltam annak a két hallgatónak a válaszát, akiknek a kérdőívéből az tűnt ki, hogy nem $\mathrm{C}$ nyelvre, hanem $\mathrm{C}$ nyelvről dolgoztak valójában.

Összesen 4 hibás kérdőív volt: kettő a gyakorlatok számát jelölte egyszer rosszul, bár két másik adat összecsengett, kettő pedig a $\mathrm{C}$ nyelvi irányt írta fordítva. Egy ötödik kérdőíven nem volt teljesen világos, hogy a hallgató tolmácsolásról vagy szinkrontolmácsolásról beszél-e, mivel arról panaszkodott, hogy általában nem szeret mások előtt beszélni (míg a szinkrontolmácsolás jellemzően kabinban, és nem „mások előtt” történik), de mivel nem volt más adat, amit figyelembe lehetett volna venni, úgy döntöttem, elfogadom a válaszát, miszerint valóban szinkrontolmácsolásra kérték fel. 


\subsection{A hallgatók válaszai}

Az alábbiakban részletesen elemezem azokat a válaszokat, amelyeket a hallgatók a szinkrontolmácsolással kapcsolatos kérdésekre adtak. Mielőtt rátérnék a kérdések egyenkénti ismertetésére, az 1. táblázatban összefoglalom, milyen gyakran kérték meg a hallgatókat arra, hogy szinkrontolmácsoljanak, annak ellenére, hogy erre a képzés során még nem készítettük fel őket.

\section{1. táblázat}

Felkérés szinkrontolmácsolásra

\begin{tabular}{|l|c|c|c|c|c|}
\hline \multicolumn{1}{|c|}{ B nyelv } & $\begin{array}{c}\text { Összes } \\
\text { gyakorlati } \\
\text { hely }\end{array}$ & $\begin{array}{c}\text { Megkérték } \\
\text { rá }\end{array}$ & Megtette & $\begin{array}{c}\text { Elégedett } \\
\text { volt }\end{array}$ & $\begin{array}{c}\text { Pozitív } \\
\text { élmény volt }\end{array}$ \\
\hline Angol & 31 & 3 & 3 & 3 & 3 \\
\hline Német & 17 & 1 & 1 & 0 & 1 \\
\hline Francia & 18 & 6 & 5 & $4-5$ & $4-5$ \\
\hline Kínai & 2 & 0 & 0 & 0 & 0 \\
\hline Összesen & 68 & 10 & 9 & $7-8$ & $8-9$ \\
\hline
\end{tabular}

Összehasonlításként érdemes megemlíteni, hogy a 68 gyakorlati hely majdnem felén, 32 helyen kérték a hallgatókat arra, hogy a C nyelvük irányába dolgozzanak, ezt 29 hallgató meg is tette, és ebből 27 elégedett is volt a teljesítményével (Seresi 2020). Ehhez képest az 1. táblázatban sokkal kisebb számok szerepelnek. Ennek természetes magyarázata az, hogy a piacon vélhetőleg eleve kevesebb igény van szinkrontolmácsolásra, mint írásbeli fordításra, illetve hogy a fordító szakos hallgatók vélhetően eleve olyan gyakorlati helyeket választottak, ahol a tolmácsolás igénye fel sem merült, vagy ahol előre tisztázták, hogy ők csak írásban szeretnének dolgozni.

A gyakorlati helyek 15\%-ában kérték a hallgatókat szinkrontolmácsolásra, és csupán egy esetben mondott a felkért hallgató nemet. Sajnos nem kérdeztem rá, melyik kitöltő volt tolmácsszakos, illetve melyik gyakorlati helyen kellett kifejezetten tolmácsolni. Ugyanakkor az évfolyam összetételét ismerve feltételezhetjük, hogy a gyakorlati helyek megközelítőleg 30\%-át tolmácsszakos hallgató töltötte be, vagyis őket az esetek felében kérhették fel szinkrontolmácsolásra. $\mathrm{Ez}$ az arány nagyon hasonló a $\mathrm{C}$ nyelvre végzett munkára felkértek arányához, de még egyszer szeretném hangsúlyozni, hogy ez a feltételezés pusztán spekuláción alapszik, a megerősítése mindenképpen további kutatást igényelne.

A szinkrontolmácsolással kapcsolatban a minta nagysága miatt (10 gyakorlati helyen kértek ilyet, és 9 esetben teljesítették a hallgatók) nem biztos, hogy érdemes nyelvek szerint tovább bontani az adatokat. Feltűnő, hogy a francia B-s hallgatókat igen gyakran kérték fel erre a tevékenységre, ami azonban ma- 
gyarázható azzal is, hogy esetleges baráti társaságok azonos vagy hasonló gyakorlati helyekre mentek (amiről nincs adat).

Az élmény megítélésével kapcsolatban felmerült némi ambivalencia is: egy hallgató jelezte, hogy volt, amikor elégedett volt a szinkronteljesítményével, és volt, amikor nem, egy másik hallgató pedig azt, hogy egyszerre volt pozitív, inspiráló, illetve elbátortalanító és negatív tapasztalat a szinkrontolmácsolás. Ez az érzelmi szélsőségesség a szinkrontolmácsolással kapcsolatban más formában is megjelent. Ugyanakkor, ha mindenkit beleszámítunk az elégedettek, illetve a pozitív élményt megélők közé, akik beszámoltak ilyenről is, elmondhatjuk, hogy a szinkrontolmácsolást kipróbálók 89\%-a elégedett volt a teljesítményével, és $100 \%$ számára pozitív, inspiráló (is) volt a tapasztalat. A szinkrontolmácsolással kapcsolatban egyetlen hallgató sem nyilatkozott úgy, hogy érzelmileg hidegen hagyta volna.

A továbbiakban azokra a hallgatókra fogok koncentrálni, akik kipróbálták a szinkrontolmácsolást a szakmai gyakorlatuk során. Ugyanakkor érdekes azt is megemlíteni, hogy összesen 5 olyan gyakorlati hely volt, ahol a hallgató mindkét vizsgált feladatot, vagyis a $C$ nyelvi irányba végzett munkát és a szinkrontolmácsolást is kipróbálta. Ezek a hallgatók a $\mathrm{C}$ nyelvre végzett munkát egységesen pozitív élménynek élték meg, és teljesítményükkel is elégedettek voltak. A szinkrontolmácsolással kapcsolatban azonban egyikük elégedetlen volt, és negatív élményként élte meg, egy másik hallgató pedig elégedett és elégedetlen is volt a teljesítményével, de összességében pozitív élményként élte meg.

Azokat a hallgatókat, akik nemet mondtak a $C$ nyelv felé végzett munkára, egyik gyakorlati helyükön sem kérték szinkrontolmácsolásra. Azt az egy hallgatót ugyanakkor, aki az egyik gyakorlati helyén elutasította a szinkrontolmácsolást, mindkét gyakorlati helyén kérték, hogy dolgozzon C nyelvre (Seresi 2020). Ezt mindkét helyen elfogadta, teljesítményével elégedett volt, az élményt pozitívan élte meg. Ezek az adatok azt sugallják, hogy a hallgatók nem feltétlenül mondanak mindenre egységesen igent vagy nemet: eltérő módon mérlegelik és ítélik meg az egyes feladatokat, illetve az azokban nyújtott teljesítményüket.

A 2. táblázatban azt foglalom össze, hogy a hallgatók mivel indokolták, elégedettek voltak-e a teljesítményükkel szinkronban. Egy-egy kérdőíven több indoklás is olvasható volt.

\section{2. táblázat}

Szinkronteljesitmény: az elégedettség vagy elégedetlenség okai

\begin{tabular}{|l|l|c|}
\hline $\begin{array}{l}\text { Elégedett volt } \\
\text { a szinkron- } \\
\text { teljesítményével? }\end{array}$ & $\begin{array}{c}\text { Említések } \\
\text { száma } \\
\text { összesen }\end{array}$ \\
\hline \multirow{3}{*}{ Igen (7 hallgató) } & Megfelelő felszerelés volt. & 1 \\
\cline { 2 - 3 } & Értettem a témához. & 1 \\
\cline { 2 - 3 } & Összeszedett volt a csapat. & 1 \\
\cline { 2 - 3 } & Sokat készültem rá. & 2 \\
\cline { 2 - 3 } &
\end{tabular}




\begin{tabular}{|l|l|c|}
\hline $\begin{array}{l}\text { Elégedett volt } \\
\text { a szinkron- } \\
\text { teljesítményével? }\end{array}$ & Miért? & $\begin{array}{c}\text { Említések } \\
\text { száma } \\
\text { összesen }\end{array}$ \\
\hline Igen (7 hallgató) & Biztosítottak anyagot a felkészüléshez. & 1 \\
\cline { 2 - 3 } & Sokat tudtam gyakorolni. & 1 \\
\cline { 2 - 3 } & $\begin{array}{l}\text { Kritikus természetủ hallgatótól nem érkezett negatív } \\
\text { visszajelzés. }\end{array}$ & 1 \\
\cline { 2 - 3 } & Kihívás volt, de jól sikerült. & 1 \\
\cline { 2 - 3 } & Átment az üzenet. & 1 \\
\cline { 2 - 3 } & Tanulhatok a hibáimból. & 1 \\
\hline \multirow{3}{*}{$\begin{array}{l}\text { Igen is és nem is } \\
\text { Kallgató) }\end{array}$} & $\begin{array}{l}\text { Kípoztam magamból a maximumot a lehetőségekhez } \\
\text { képt. }\end{array}$ & 1 \\
\cline { 2 - 3 } & Nem biztosítottak megfelelő körülményeket. & 1 \\
\hline \multirow{3}{*}{ Nem (1 hallgató) } & Nagyon fel kell készülni. & 1 \\
\cline { 2 - 3 } & Nagyon összeszedettnek kell lenni. & 1 \\
\cline { 2 - 3 } & Nem szeretek szerepelni. & 1 \\
\hline
\end{tabular}

A hallgatók indoklásaikban legfontosabb tényezőként a felkészülés, a megbízók által biztosított körülmények és a visszajelzés fontosságát hangsúlyozzák. Felmerül továbbá szempontként a munka kézzelfogható eredménye (megvalósult a kommunikáció), valamint a kihívást jelentő feladat sikeres teljesítése felett érzett elégedettség.

Végül a 3. táblázatban azt tekintem át, milyen érzelmi útravalót jelentett a hallgatóknak a szinkrontolmácsolás. Ebben a táblázatban azt tüntetem fel, hogy az adott indoklás összesen hány kérdőíven szerepelt, és ebben az esetben is akadt olyan kérdöív, amelyre több indoklást is írtak a hallgatók.

\section{3.táblázat}

Szinkrontolmácsolás kipróbálása: az érzelmi benyomások okai

\begin{tabular}{|l|l|c|}
\hline $\begin{array}{l}\text { Milyen érzelmi } \\
\text { benyomást tett } \\
\text { Önre a szink- } \\
\text { rontolmácsolás } \\
\text { kipróbálása? }\end{array}$ & Miért? & $\begin{array}{c}\text { Említések } \\
\text { száma } \\
\text { összesen }\end{array}$ \\
\hline $\begin{array}{l}\text { Pozitív, inspiráló, } \\
\text { önbizalom-növe- } \\
\text { lő (7 hallgató) }\end{array}$ & Ismertem a témát. & 1 \\
\cline { 2 - 3 } & Jó volt a felszerelés. & 1 \\
\cline { 2 - 3 } & $\begin{array}{l}\text { Tudtam, hogy amikor rosszul sikerült, az azért volt, } \\
\text { mert nem biztosítottak megfelelö körülményeket. }\end{array}$ & 1 \\
\cline { 2 - 3 } &
\end{tabular}




\begin{tabular}{|c|c|c|}
\hline $\begin{array}{l}\text { Milyen érzelmi } \\
\text { benyomást tett } \\
\text { Önre a szink- } \\
\text { rontolmácsolás } \\
\text { kipróbálása? }\end{array}$ & Miért? & $\begin{array}{l}\text { Említések } \\
\text { száma } \\
\text { összesen }\end{array}$ \\
\hline \multirow[t]{7}{*}{$\begin{array}{l}\text { Pozitív, inspiráló, } \\
\text { önbizalom-növe- } \\
\text { lő ( } 7 \text { hallgató) }\end{array}$} & $\begin{array}{l}\text { A tolmácsolásom nélkül a közönség semmit sem értett } \\
\text { volna. Hozzásegítettem őket a megértéshez. }\end{array}$ & 2 \\
\hline & $\begin{array}{l}\text { Rájöttem, hogy nem olyan nehéz, mint amilyennek } \\
\text { gondoltam. }\end{array}$ & 1 \\
\hline & Felemelő / jó érzés volt, amikor jól sikerült. & 3 \\
\hline & Fáradtság helyett azt éreztem, hogy felpörgetett. & 1 \\
\hline & Izgalmas volt a helyzet kiszámíthatatlansága. & 1 \\
\hline & $\begin{array}{l}\text { Kiderült, hogy } 60 \text { percig is képes vagyok koncentrálni, } \\
\text { ha muszáj (sic). }\end{array}$ & 1 \\
\hline & Pozitív visszajelzést kaptam. A közönség hálás volt. & 2 \\
\hline \multirow{2}{*}{$\begin{array}{l}\text { Pozitív és negatív } \\
\text { is egyszerre ( } 1 \\
\text { hallgató) }\end{array}$} & $\begin{array}{l}\text { Volt, hogy éreztem, nem sikerült jól, és sajnáltam } \\
\text { a közönséget, hogy csak ilyen tolmácsolást kap. }\end{array}$ & 1 \\
\hline & Pozitív visszajelzést kaptam. & 1 \\
\hline \multirow{2}{*}{$\begin{array}{l}\text { Negatív, } \\
\text { elbátortalanító } \\
\text { hatása volt ( } 1 \\
\text { hallgató) }\end{array}$} & Túlságosan befolyásol, mások mit gondolnak rólam. & 1 \\
\hline & Többet kellene emberek előtt beszélnem. & 1 \\
\hline $\begin{array}{l}\text { Nem tett rám } \\
\text { különösebb } \\
\text { hatást (0 } \\
\text { hallgató) }\end{array}$ & - & - \\
\hline
\end{tabular}

Szembetűnik, hogy a szinkrontolmácsolás érzelmileg megosztóbb a C-re végzett munkánál, amellyel kapcsolatban 29-ből 7 gyakorlati hely esetében a hallgatók úgy nyilatkoztak, nem tett rájuk különösebb érzelmi benyomást a feladat (Seresi 2020). A szinkrontolmácsolás ezzel szemben senkinek nem volt közömbös élmény, sőt, volt, aki a saját teljesítményét is ellentmondásosan ítélte meg.

$\mathrm{Az}$ indoklások szövegében olyan kifejezések is előfordulnak, mint ,izgalmas”, „felemelő”, „kiszámíthatatlanság”, „hála” vagy „felpörögtünk” - míg a C nyelvre végzett munkánál sokan unalomról vagy közönyről számoltak be (Seresi 2020).

Különösen szembetűnő és pozitív meglepetés, mennyire élénken foglalkoztatta a hallgatókat a közönség - annak ellenére, hogy a szinkronkabin valamennyire elszigetelte őket hallgatóságuktól. Többen említik, hogy fontos volt számukra, milyen minőségü tolmácsolást kaptak hallgatóik, és ismét sokan említették a visszajelzéseket is. 
Ugyanakkor ismét felmerülhet a kérdőívek olvasóiban a kérdés, hogy ezek a tolmácsolások mennyiben voltak összhangban a szakmai standardokkal. Mennyire voltak tisztában a hallgatók azzal, milyen körülményekre lenne szükségük a munkájuk elvégzéséhez, és mennyire tudták ezek szükségességét megindokolni a megbízók felé. Mindenképpen pozitívum, hogy többen hangsúlyozták a felkészülés fontosságát, illetve frusztrációjukat, ha úgy érezték, a nem megfelelő körülmények miatt nem nyújtották a maximumot. Ugyanakkor csak remélni lehet, hogy az egyik hallgató hatvan perces megszakítatlan koncentrálásról írt szavait nem úgy kell értelmezni, hogy írójuk képzettség nélkül egy órán keresztül egyedül szinkrontolmácsolt.

Több hallgató írta, hogy pozitív visszajelzést kapott. A visszajelzésekkel kapcsolatban azonban mindenképp meg kell jegyezi, hogy a megbízók és az ügyfelek között nem mindenki volt szakember, így a visszajelzésük pontossága megkérdőjelezhető (Gile 1995). Ugyanakkor a megbízók és ügyfelek szempontjából az az elsődleges, hogy úgy érezzék, a nyelvi közvetítőnek köszönhetően maradéktalanul megvalósult a kommunikáció (Jones 1998).

És valóban: egy igen elgondolkodtató megjegyzés szerint pozitívan hatott a tolmácsra, hogy ha ő nincs ott, a résztvevők egyáltalán nem értették volna az előadást. Ezt az érvet gyakran hozzák fel olyan tolmácsok, akik valamilyen szakmailag kifogásolható körülmény ellenére is elfogadják a megbízást. És bár igaz, hogy az adott helyzetben valóban úgy látszik, hogy a képzettségüket (és sejthetően képességeiket) meghaladó megbízást elfogadó hallgatók nélkül meghiúsulna a kommunikáció, a kérdést máshogy is fel lehet fogni. Ha ugyanis eleve nemet mondanának az ilyen megbízásokra, a megbízók kénytelenek lennének képzett tolmácsokat hívni. Feltételezhetjük, hogy ebben az esetben a közönség teljesebb, informatívabb tolmácsolást kapott volna - igaz, több pénzért.

Úgy tünik, a magyarországi tolmácspiacon még ma is sok olyan szegmens van, ahol a megbízók vagy akár a konferenciaközönség is szemmel láthatóan megbecsüli a nem teljesen kiképzett tolmácshallgatók szolgáltatását is, hiszen nélkülük semmilyen értés vagy kommunikáció sem valósulhatna meg. Nálunk nem teljesedett be még tehát Donovan (2006) jóslata, miszerint a globalizált világban az olcsó utazásnak, a megszünő határellenőrzéseknek, valamint az interneten szinte korlátlanul elérhető idegen nyelvü dokumentumoknak és videofelvételeknek köszönhetően a konferenciák hallgatósága többé-kevésbé érteni fogja az elterjedtebb, „nagy” nyelveket. Így a tolmácsolás számukra inkább kényelmi szolgáltatás lesz, amit csak akkor fizetnek meg, ha a minősége meghaladja a saját nyelvtudásuknak köszönhetően is megvalósítható kommunikáció minőségét.

\section{Konklúzió}

Írásomban, amely az Iránytü az egyetemi tolmácsképzéshez címü kötetben megjelenő cikkem (Seresi 2020) második része, az ELTE FTT mesterképzésében részt vevő hallgatók szakmai gyakorlatát vizsgáltam meg. Kérdőívvel mértem fel, hogy milyen gyakran kérik a hallgatókat a szakmai gyakorlaton olyan feladatok teljesítésére, amelyre a képzés során nem volt alkalmuk felkészülni. 
A cikk első részében a $C$ nyelvi irányba végzett fordítással és tolmácsolással kapcsolatban begyüjtött adatokat elemeztem. A második részben áttekintettem a szinkrontolmácsolás elkezdésére vonatkozó szakirodalmat és történelmi tapasztalatokat, majd azt vizsgáltam meg, milyen gyakran kérik az erre fel nem készített hallgatóinkat, hogy a szakmai gyakorlatukon szinkrontolmácsoljanak.

Kérdőíves kutatásom legfontosabb konklúziója, hogy a szakmai gyakorlatokon kifejezetten gyakran kérik a hallgatókat, hogy olyan szerepet töltsenek be, amelyekre a képzés nem készítette fel őket. Különösen azt kérik gyakran, hogy a hallgatók a C nyelvükre dolgozzanak (Seresi 2020), de szinkrontolmácsolást is viszonylag gyakran kérnek a hallgatóktól: a gyakorlati helyek egy hetedén került erre sor. A hallgatók az ilyen irányú kéréseket gyakorlatilag mindig teljesítik. Az esetek igen jelentős többségében elégedettek az elvégzett munkával, és az élményt majdnem ugyanilyen elsöprő arányban pozitívnak, inspirálónak élik meg. A pozitív benyomások mögött elsősorban a pozitív visszajelzések, a felkészülés és a gyakorlati hely által biztosított körülmények állnak. Ugyanakkor a szinkrontolmácsolás kipróbálása érzelmileg igen intenzív élményt jelent a hallgatóknak, amelyre egyikük se reagált közönyösen: többen ellentmondásos érzelmekről számoltak be, és jellemzően érzelmileg erősen telített szavak használatával számoltak be élményeikről.

A kutatás egyértelmúen pozitív konklúziója, hogy sok hallgató tisztában van vele, milyen fontos szerepet játszik a teljesítményükben a felkészülés, illetve az, hogy a megbízó biztosítsa a megfelelő feltételeket (például kabint, felkészülési anyagokat). Ugyanakkor mivel sokan még a konszekutív tolmácsolásból sem érték el a záróvizsgán elvárt szintet (hiszen a gyakorlat idején még egy teljes tanév állt előttük), vélhetően nem álltak készen arra, hogy megfelelő minőségű szinkronteljesítményt nyújtsanak. Teljesítményükről csak saját benyomásaikat ismerjük, bár sejthető, hogy az új, nehezebb feladat elvégzése annyira lekötötte a kognitív kapacitásukat, hogy nem feltétlenül jutott energiájuk teljesítményük objektív monitorozására. A pozitív visszajelzésekről is csak elmondásukból tudunk, és szakmailag ezek megalapozottsága is vitatható (Gile 1995).

A kérdőívben nem kérdeztem rá, és a hallgatók sem említették, volt-e partnerük a kabinban, és ha igen, hogyan tudtak együttműködni. Általában csak nagyon általánosan említették a „körülményeket” vagy a „megfelelő felszerelést", ami utalhat arra, hogy nem tudják még ezeket részletesen elemezni, de arra is, hogy egyszerüen nem volt kedvük ezeket a körülményeket hosszabban kifejteni. A magyarországi tolmácspiacról azonban mindenképpen érdekes képet adna, ha az anekdotákon túlmenő empirikus kutatás születne arról, pontosan milyen körülmények biztosítása mellett várják el a megbízók a szinkronteljesítményt.

További érdekes kutatási téma lehet, hogy mi alapján mondtak a hallgatók a felkérésekre igent vagy nemet. Összefügg-e ez vajon azzal, hogy kezdőként nem szívesen mondtak nemet egy megbízásra, vagy inkább úgy ítélték meg, nem vállalnak jelentős kockázatot, ha ismeretlen területre merészkednek. A különböző nyelvkombinációk közötti eltéréseket is érdemes lett volna részletesebben megvizsgálni, bár ehhez nagyobb mintára lett volna szükség. 
Arra is érdekes lett volna rákérdezni, hogy a tolmácshallgatóknak milyen mértékben volt lehetőségük tolmácsolási munkákat végezni a gyakorlat során, és hogy volt-e irányukban jelentős igény nem szinkron módban végzett tolmácsolásra. Vagyis: mennyire kellett a hallgatóknak kompromisszumot kötniük annak érdekében, hogy egyáltalán határidőre teljesíthessék a gyakorlatukat, lehetőleg az általuk választott specializációnak megfelelően.

Kutatásommal kimutattam, hogy a magyarországi nyelvi közvetítői piacon elterjedtek az olyan gyakorlatok, amelyek nem felelnek meg a nemzetközi szakmai standardoknak. A képző intézmények felelőssége, hogy tudatosítsa a hallgatókban a szakmai standardok fontosságát, illetve felkészítse őket arra, hogy a piacra kikerülve a laikus és szakmabeli megbízók felé is képesek legyenek megindokolni, miért ragaszkodnak ezekhez a standardokhoz. Ez a piac minden szereplöjének érdeke. Ugyanakkor a nyelvi közvetítői szakmában mindig jelen volt a kockázatvállalás és az újdonságok kipróbálása is - hiszen e nélkül maga a szinkrontolmácsolás se jöhetett volna létre. Úgy vélem, ha a hallgatóinkat megfelelően felkészítjük saját teljesítményük monitorozására, valamint a saját teljesítményükkel és a megbízóval szembeni felelősség vállalására, bizonyos körülmények között sikerrel vállalhatnak számukra újdonságot jelentő feladatokat is.

\section{Irodalom}

AIIC, 2001. Advice to students wishing to become conference interpreters. https://aiic.net/ page/56/advice-to-students-wishing-to-become-conference-interpreters/lang/1 (letöltve: 2019. július 3.)

Chmiel, A. 2008. Boothmates forever? - On teamwork in a simultaneous interpreting booth. Across Languages and Cultures. Vol. 9. No. 2. 261-276

Donovan, C. 2006. Trends - Where is Interpreting heading and how can training courses keep up? Contribution at the EMCI conference: The Future of Conference Interpreting: Training, Technology and Research, 30 June -1 July 2006. https://www. emcinterpreting.org/emci_drupal_data/Where $\% 20$ is $\% 20$ interpreting $\% 20$ heading\%20Donovan.pdf (letöltve: 2019. július 3.)

Gile, D. 1995. Basic Concepts and Models for Interpreter and Translator training. Amsterdam/Philadelphia: John Benjamins Publishing Company.

G. Láng, Zs. 2002. Tolmácsolás felsőfokon. Budapest: Scholastica

Herbert, J. 1952. The Interpreter's Handbook: How to become a conference interpreter. Genf: Librairie de l'Université George.

Horváth I. 2012. Interpreter Behaviour. A psychological approach. Budapest: Hang Nyelviskola Bt.

Jones, R. 1998. Conference Interpreting Explained. Manchester: St. Jerome Publishing.

Kalina, S. 2002. Interpreters as professionals. Across Languages and Cultures Vol. 3. No. 2. 169-187.

Klaudy, K. 1999. Bevezetés a forditás elméletébe. Budapest: Scholastica.

Moser-Mercer, B. Künzli, A. Korac, M. 1998. Prolonged turns in interpreting: Effects on quality, physiological and psychological stress (Pilot study). Interpreting. Vol. 3. No. 1. 47-64.

Rohonyi, B. 2018. A szöveggel támogatott szinkrontolmácsolás vizsgálata angol-magyar nyelvi irányban. Doktori disszertáció. ELTE FTT 
Seleskovitch, D., Lederer, M. 2002. Pédagogie Raisonnée de l'Interprétation. Paris: Didier Érudition.

Seresi, M. 2016. Távtolmácsolás és távoktatás a tolmácsképzésben. Budapest: ELTE Eötvös Kiadó.

Seresi, M. 2019. A tolmácsolás szakmai standardjainak kialakulása és érvényesülése a gyakorlatban. In: Szoták, Sz. (szerk.) 2019. Diszciplínák találkozása: nyelvi közvetités a XXI. században. Budapest: OFFI. 135-145

Seresi, M. 2020. Fordító- és tolmácshallgatók gyakornoki tapasztalatai: elvárások és gyakorlatok. 1. rész: Fordítás és tolmácsolás C nyelvre. In: Szabó, Cs., Bakti, M. (szerk) (elökészületben). Iránytü az egyetemi tolmácsképzéshez. Pécs: Kontraszt.

Setton, R., Dawrant, A. 2016. Conference Interpreting. A Trainer's Guide. Amsterdam/ Philadelphia: John Benjamins Publishing Company

Szabari, K. 2002. Tolmácsolás. Bevezetés a tolmácsolás elméletében és gyakorlatába. Budapest: Scholastica.

Zeier, H. 1997. Psychophysiological stress research. Interpreting. Vol 2. No. 1-2. 231249.

\section{Függelék}

\section{Kérdöiv a szakmai gyakorlattal kapcsolatban}

Kérem, töltse ki ezt a kérdőívet az ELTE FTT mesterképzéshez végzett szakmai gyakorlatával kapcsolatban! A válaszoknak köszönhetően jobban megismerhetjük a magyar nyelvi közvetítői piacon elterjedt gyakorlatokat. Segítségét előre is köszönöm!

Seresi Márta

1. Hány helyen végezte a szakmai gyakorlatát? A választ jelölje X-szel.

Egy helyen

Két helyen

Három helyen

2. A gyakorlat során előfordult, hogy azt kérték Öntől, hogy dolgozzon a C nyelvére?

$\bigcirc$ Nem fordult elő (Kérem, ugorjon a 8-as kérdésre!)

Igen, egy helyen

Igen, két helyen

Igen, három helyen 
3. Teljesítette ezt a kérést?

Nem (Kérem, ugorjon a 8-as kérdésre!)

Igen, összesen egy gyakorlati helyen

Igen, összesen két gyakorlati helyen

Igen, összesen három gyakorlati helyen

4. Ha teljesítette, összességében elégedett volt ilyenkor a saját teljesítményével?

Inkább elégedett voltam

Inkább elégedetlen voltam

5. Mit gondol, miért volt elégedett/elégedetlen a saját teljesítményével?

6. Ha teljesítette a kérést, összességében milyen élmény volt az ilyen munka?

Inkább inspiráló, önbizalom növelő élmény volt

Nem tett rám különösebb érzelmi hatást

Inkább elbátortalanító élmény volt, a hatására kételkedni kezdtem a képességeimben

7. Mit gondol, miért volt Önre ilyen hatással?

8. A gyakorlat során előfordult, hogy azt kérték Öntől, hogy szinkrontolmácsoljon?

Nem fordult elö

Igen, egy helyen

$\bigcirc$ Igen, két helyen

Igen, három helyen 
9. Teljesítette ezt a kérést?

\section{$\bigcirc$ Nem}

$\bigcirc$ Igen, összesen egy gyakorlati helyen

$\bigcirc$ Igen, összesen két gyakorlati helyen

Igen, összesen három gyakorlati helyen

10. Ha teljesítette, összességében elégedett volt ilyenkor a saját teljesítményével?

Inkább elégedett voltam

Inkább elégedetlen voltam

11. Mit gondol, miért volt elégedett/elégedetlen a saját teljesítményével?

12. Ha teljesítette a kérést, milyen élmény volt az ilyen munka?

Inkább inspiráló, önbizalom növelö élmény volt

Nem tett rám különösebb érzelmi hatást

Inkább elbátortalanító élmény volt, a hatására kételkedni kezdtem a képességeimben

13. Mit gondol, miért volt Önre ilyen hatással?

Köszönöm a kitöltést! Az eredményekről a HÖK-ös hallgatókon keresztül beszámolok. 